\title{
Turizmin Yerel Ekonomik Etkilerinin Belirlenmesi: Marmaris Otelcilik Endüstrisi Örneği*
}

Determination of Local Economic Impacts of Tourism: The Case Of Marmaris Hotel Industry

\author{
Mustafa TERZioĞLU*, Ummuhan GÖKOVALI** \\ *Yrd. Doç.Dr., Muğla Sıtkı Koçman Üniversitesi, i̇.i.B.F., İktisat Bölümü, 48000, Kötekli, Muğla. \\ E-posta: mterzioglu@mu.edu.tr \\ **Prof. Dr., Muğla Sıtkı Koçman Üniversitesi, i̇.i.B.F., İktisat Bölümü, 48000, Kötekli, Muğla. \\ E-posta: ummuhan@mu.edu.tr
}

MAKALE BILGILERI

Makale ișlem bilgileri:

Gönderilme tarihi:25 Nisan 2016

Birinci düzeltme: 18 Mayıs 2016

Kabul: 28 Haziran 2016

Anahtar sözcükler: Turizmde ekonomik bağlantılar, Turizmde ekonomik sızıntılar, Turizmin ekonomik etkileri, Marmaris otelcilik endüstrisi.

\section{ARTICLE INFO}

Article history:

Submitted: 25 April 2016

Resubmitted: 18 May 2016

Accepted: 28 June 2016

Key words: Economic linkages in tourism, Economic leakages in tourism, Economic impacts of tourism, Marmaris hotel industry. öz

Turizm endüstrisi ekonomik büyüme, istihdam yaratma, ödemeler dengesi kısıtlarını kolaylaștırma ve yerli ve yabancı sermayeyi teşvik eden özelliklerden dolayı özellikle gelişmekte olan ülkelerde lokomotif endüstriler arasında yer almaktadır. Ancak turizmin yerel ve ulusal net ekonomik etkilerinin belirlenebilmesi için öncelikle ekonomik sızıntıların tespit edilmesi gerekmektedir. Turizmin yerel ekonomiye yaptığı katkıları ekonomik sızıntıları göz önünde bulundurarak ortaya koyan birçok uluslararası çalışma olmasına rağmen Türkiye'de böyle bir çalışmaya rastlanmamıştır. Alanyazındaki bu eksikliği gidermek amacıyla Muğla ilinin Marmaris ilçesinde faaliyet göstermekte olan 4 ve 5 yıldızlı otel ve tatil köylerinin yöneticilerine ( 52 tesisten 33 tanesi ile) yarı-yapılandırılmış anket uygulanmıș ve Marmaris otelcilik endüstrisinde ekonomik sızıntılar ve bağlantılar tespit edilmiştir. Alan araştırmasından elde edilen veriler, Keynezyen çarpan yardımı ile otelcilik endüstrisinin gelir, istihdam ve vergi geliri üzerindeki etkileri tahmin etmek için kullanıımıştır. Tahminler turizm endüstrisinin Marmaris ekonomisi için lokomotif sektör olma özelliğini pekiștirici niteliktedir.

\section{ABSTRACT}

Tourism industry has been among the leading sectors for especially developing countries due to its contribution to economic growth, creation of employment, easing balance of payment constraints and encouragement of foreign direct investment. However, to assess the net local and nation-wide contribution of tourism sector, it is necessary to lay out the economic leakages. Although there are many international studies which investigated the local economic contribution of tourism sector taking into account the economic leakages, there is no such study for Turkey. To fill this gap, a detailed semi-structured questionnaire is applied to managers of 4 and 5-star hotels and holiday villages (33 out of 52) that are active in the district of Marmaris-Mugla-Turkey and economic leakages and linkages of Marmaris hotel sector has been identified. Data obtained from the field survey is used to estimate economic effects of hotel industry such as creation of employment and tax income and generation of income by hotels through Keynesian multiplier. The estimation results confirm that hotel industry has indeed a leading sector for the Marmaris economy.

\section{GíRiş}

Turizm gerek gelişmiş gerekse gelişmekte olan ülkeler açısından kalkınma, büyüme, yatırımlar ve istihdam üzerine olan etkileri açısından kalkınmanın ilk aşamasında teşvik edilen endüstriler arasındadır. Bunun yanı sıra turizm, belli

* Bu çalışmanın alan araştırması, TÜBİTAK tarafından 112K514 no'lu Araştırma Projesi (1001) kapsamında desteklenmiştir. bir bölgenin ve yörenin gelişmesi için de önemli sektörlerden biridir. Turizmin bir yörenin ekonomisine olan katkısı turizmin diğer endüstrilerle olan ileri ve geri bağlantıları yolu ile ortaya koyulabilir. Turizm endüstrisi otel, restoran ve diğer turizm ile ilişkili faaliyetleri yaratmak ve yönetmek için geri bağlantılar yoluyla enerji, telekomünikasyon, çevre, tarım, imalat ve inşaat gibi temel endüstrilerden desteğe ihtiyaç duyar. 
Turizm endüstrisinin turistlerin tükettiği diğer ürünlerin sağlayıcısı olan finans, telekomünikasyon, perakende, eğlence, kültürel, güvenlik ve sağlık gibi endüstriler ile de ileri bağlantıları söz konusudur. Güçlü bağlantılar çarpan etkisiyle, ulusal düzeyde turizmin ekonomik faydalarını artırıcı etkide bulunurken, yerel düzeyde de turizmin geliri ve istihdam olanaklarını artırıcı ve yoksulluğu azaltıcı etkilerini çoğaltır (UNCTAD 2010).

Turizmin yerel ekonomi ile bağlantılarını ve yerel ekonomiye yaptığ 1 katkıları inceleyen birçok uluslararası çalışma olmasına rağmen Türkiye'de otel endüstrisinin yerel ekonomi ile olan bağlantılarını, yarattığı ekonomik katkıları ve sızıntıları araştıran ve detaylı bir biçimde ortaya koyan çalışmaya rastlanmamıştır. Bu çalışmada alanyazındaki bu eksikliği gidermek amacıyla Türkiye'nin en önemli turizm merkezlerinden biri olan Muğla ilinin Marmaris ilçesinde faaliyet göstermekte olan ana kütlesini 4 ve 5 yıldızlı otel ve tatil köylerinin oluşturduğu 52 tesisten 33 'ünden yüzyüze görüşme ve anket teknikleri yolu ile veri toplanmış ve Marmaris otelcilik endüstrisinin yerel ekonomi ile olan bağlantıları tespit edilmiştir. Bu veriler kullanılarak otelcilik endüstrisinin yarattığ 1 istihdam ile bu sektörde alınan toplam ücretler ve otellerin girdi satın almaları yoluyla yaptığ ve bunların yeniden harcanması ile yerel ekonomide yaratacağı ekonomik etki çarpan yardımıyla tahmin edilmiştir. Ayrıca otel başına hesaplanan gelir verisi üzerinden toplam net kar ve vergi ödemeleri hesaplanmıştır. Son olarak sektörde oluşan dışsal sızıntının tutarı hesaplanarak elde edilemeyen turizm gelirleri tahmin edilmiştir. $\mathrm{Bu}$ hesaplamalar ve tahminler ile Türkiye alanyazınında bir boşluk doldurulmuştur.

Çalışmanın ilk bölümünde turizmin ekonomik etkilerinden olan kalkınma, büyüme, yatırımlar ve istihdam ile olan ilişkileri değerlendirilmiştir. Sonraki bölümde ise araştırma kapsamında elde edilen veriler yardımıyla, Marmaris geneli için istihdam, ücret, gelir ve ithalat gibi ana değişkenler açısından otelcilik sektörünün yerel ekonomi ile olan bağlantıları çarpan analizi yöntemi ile tahmin edilmektedir. Sonuç bölümü ise politika önermelerine ayrılmıştır.

\section{TURIZMIN EKONOMIK ETKILERI}

Turizm endüstrisi döviz kazandıran, istihdam yaratan, yerli ve yabancı sermayeyi cezbeden ve ekonomik bağımsızlığı teşvik eden niteliklere sahip olması (Britton 1982) nedeniyle az gelişmiş ve gelişmekte olan ülkeler için genellikle kalkınma stratejisi olarak benimsenmiştir. Ekonomik kalkınma için geleneksel tarım ekonomisinden endüstriyel ekonomiye dönüşüm yüksek düzeyde sermaye ve döviz kazancı gerektirmekte ve bu gereksinim gelişmekte olan ülkelerdeki kamu otoritelerinin turizmi ekonomik kalkınma için gerekli olan finansal kaynağı yaratıcı bir araç olarak görmelerine neden olmaktadır (Wall ve Mathieson 2006). Birleşmiş Milletler Dünya Turizm Örgütü (UNWTO) (2002) istihdam yaratma potansiyeli, yerel ekonomiyle bağlantıları, döviz kazandırması ve çarpan etkisiyle turizm sektörünün ekonomik büyümeye ve kalkınmaya öncülük edebilecek potansiyele sahip olduğunu belirtmektedir. Örneğin, ihracata önemli katkılar sağlayan sektörlerin sıralandığ listede, turizm endüstrisi 150 ülke için ilk beşte yer alırken, 60 ülkede ise ilk sırada yer almaktadır. Bunun yanı sıra turizm, gelişmekte olan ülkelerin üçte birinde ve az gelişmiş ülkelerin yarısında ülkenin ana döviz kaynağını oluşturmaktadır (UNCTAD 2010; UNEP ve UNWTO 2012). Dünya Seyahat ve Turizm Konseyi (WTTC) (2008), dünya turizm ve seyahat faaliyetlerinde 2009 ve 2018 yılları arasında yıllık olarak ortalama $\% 4,4$ oranında büyüme kaydedileceğini, 297 milyon istihdam yaratılacağını ve küresel hasılanın \%10,5'ini oluşturacağını öngörmektedir.

Turizm yerel ekonomik kalkınma için de önemli bir sektördür. Turizm harcamaları, turizm tesislerinin ve turizmin arz zincirinin yapısına bağlı olarak yerel ekonomiye dahil olur. Eğer bu yapı kuvvetli ve turizm sürdürülebilirlik kazanmış ise turizm kalkınmaya önemli katkılar sağlar. Turizm harcamaları, tarım, el sanatları, ulaşım, su ve çöp arıtımı, enerji ve diğer birçok sektörde doğrudan veya dolaylı talep artışlarına yol açar. Diğer taraftan bir turizm bölgesinde turizm talebine yönelik girdilerin (yatak, çarşaf, örtü, gıda, içecek, makine, teçhizat, iş gücü, tur ve ulaşım hizmetleri vb.) yerel firmalardan karş1- 
lanma oranı ne kadar yüksekse, turizm harcamalarının yerel ekonomiye katkısı o kadar yüksek olacaktır. Bunun yanı sıra turizm bölgelerinde, karayolu, su ve enerji kaynakları gibi altyapı yatırımları gereksinimi doğmakta ve bunlar kamu sektörü tarafından sağlanmaktadır. Bu yatırımlar aslında diğer sektörlerin de gelişmesine katkıda bulunurken, yöredeki yaşam kalitesini yükseltmektedir (UNEP ve UNWTO 2012).

Turizmin ekonomik büyümeye olan etkisi ise alanyazında üzerinde çok durulan konulardan biridir. Turizm sektörünün büyümesiyle birlikte, ilişki içinde olduğu tarım ve sanayi gibi birçok sektörde faaliyet gösteren işletmeler, turizm sektörünün talepleri doğrultusunda üretimlerini artırma ve çeşitlendirme yoluna gitmektedir. $\mathrm{Bu}$ tür gelişmelerin ve ilişkilerin ışığında, turizmin gelişmesinin ve büyümesinin ekonomik büyümeye genellikle olumlu yönde katkıda bulunduğu görüşü kabul görmektedir (Dritsakis 2012). Turizm gelirlerinin 1970-2012 yılları arasında yaklaşık 60 katına yükseldiği (UNWTO 2013), 2012 y1lında turizm endüstrisinin küresel milli gelire doğrudan katkısının \%2,9, dolaylı ve uyarılmış etkileri de kapsayan toplam katkısının ise $\% 9,3$ olduğu belirtilmektedir (WTTC 2013). Ivanov ve Webster (2013) turizmin ekonomik büyümeye katkısının en yüksek olduğu bölgelerin sirasiyla Afrika, Asya, Latin Amerika ve Karayipler olduğunu belirtmektedir. Eugenio-Martin vd. (2004) ise 21 Latin Amerika ülkesi için yaptıkları çalışmada turizmin ekonomik büyümeye katkısının düşük ve orta gelirli ülkelerde belirgin olduğunu, ancak bu ilişkinin zengin ülke grubunda söz konusu olmadığını belirtmişlerdir.

Turizm aynı zamanda döviz kazandırma potansiyeli nedeniyle ödemeler dengesine olumlu etki yaratabilecek bir sektördür. Vellas ve Becherel (1995) turizmin birçok ülkede ödemeler dengesini istikrarlandırıcı etki yarattığını ileri sürerken Sinclair ve Stabler (1997) aksine, turizmin istikrarsızlığa eğilimli bir sektör olduğunu belirtmişlerdir. Bu durum turizmin isteğe bağlı tüketim harcamaları arasında yer almasından ve turizmin küresel ekonomik dalgalanmalara duyarlı olmasından kaynaklanmaktadır. Turizm ile ilişkili harcamalar gıda, giyinme ve barınma vb. gibi zorunlu tüketim harcamalarına nazaran daha fazla isteğe bağlı niteliklidir ve ekonomik daralma dönemlerinde harcamaları ilk azaltılan sektördür.

Özellikle gelişmekte olan ülkelerde sanayileşme süreci ile birlikte turizme destek verilmesi turizm alanında yatırımları arttırmaktadır. Bunlar yol yapımı, elektrik ve su temini gibi altyapı yatırımları olabileceği gibi turizm tesisinin yapılması ve faaliyete geçmesi aşamasında birçok alanda yatırım yapılması şeklinde de olabilir. Turizm sektörü aslında çarpan etkisi yaratarak ülkedeki diğer sektörlere de katkı sağlar. Bu sektörler inşaat, ulaşım, tekstil, tarım ve balıkçılık gibi sektörlerdir (Tyrrell ve Jonhston 2001) ve turizm sektörünün gelişmesi ile uyarılan bu sektörlerde de yatırım, istihdam ve gelir artışları meydana gelir.

Turizm sektörü emek yoğun yapısı itibariyle yüksek istihdam olanakları sağlarken, özellikle düşük ve yarı nitelikli iş gücüne iş bulma fırsatı sunar. Turizm dünyada en yüksek istihdam olanağ sağlayan sektör konumuyla, özellikle kadin ve genç nüfus ve göç eden işçilere istihdam sağlama açısından lider sektörler arasındadır. WTTC'ye (2008) göre turizm sektörü dünya genelinde 220 milyon iş imkânı yaratımıyla \% 8 'lik bir paya sahiptir. Turizm sektöründeki istihdamin yaklaşık \%70'i kadınlardan oluşmaktadır, yaklaşık olarak bunun yarısı da 25 yaş ve altı profile sahiptir. Turizm sektörünün 2020 itibariyle yaklaşık 60 milyon yeni iş olanağı yaratması beklenmektedir (ILO 2008; UNEP 2011; UNEP ve UNWTO 2012).

Turizmin ekonomik büyümeye (Gökovalı 2010; Dritsakis 2012; Othman vd. 2012), yatırımlara (Moore ve Craigwell 2008; Othman vd. 2012), istihdama (Archer ve Fletcher 1996; Aguayo 2011) ve ödemeler dengesine (Shan ve Wilson 2001; Hanafiah ve Harun 2010) olan ekonomik etkileri bir çok teorik ve ampirik araştırmaya konu olurken turizmin vergi gelirlerine ve enflasyona olan etkileri çok fazla araştırılan konular arasında değildir ${ }^{1}$. Turizm harcamalarının otomatik olarak

\footnotetext{
${ }^{1}$ Bu konulardaki daha kapsamlı alanyazın taraması için bak1nız Terzioğlu (2014).
} 
ekonomideki toplam harcama düzeyini artırması ve buna paralel olarak vergi gelirlerinin artmasi beklenmektedir (Roussot 2005). Mathieson ve Wall'a (1982) göre turizm kaynaklı başlıca vergi geliri, doğrudan vergiler ve gümrük vergileri yoluyla elde edilmektedir. Enflasyonist etki ise turistlerin harcamaları yoluyla ortaya çıkmaktadır. Genellikle turistler bir ürünü yerel halktan daha yüksek fiyata satın almaktadır. Akama ve Kieti (2007) ve Sebastian ve Rajagopalan (2009) turizmin arz ve talebinin artmasiyla birlikte gida ve diğer ürünlerin fiyatlarının yükseldiğini tespit etmiştir. Bir diğer enflasyonist etki ise turizmin gayrimenkul talebini artırarak gayrimenkul fiyatlarını yükseltmesi nedeniyle oluşur (Roussot 2005).

Turizm endüstrisi yüksek sızıntılara sahip olması nedeniyle de eleştirilmekte ve yerel ekonomiye yaptığı katkıların boyutu konusunda ortaya çıkan şüpheler artmaktadır (Bryden 1973; Britton 1982). Ekonomik bağlantılar ile ters yönlü ilişki içinde olan ekonomik sızıntılar bir süreç olarak,

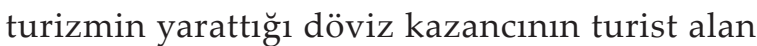
ülkede kalmayıp, turist yaratan ülkelerin veya diğer yabancı firmaların eline geçmesi ile ortaya çıkar. Birçok gelişmekte olan ülke için ortalama sızıntı oranı \%40-50 iken gelişmiş veya daha çeşitlenmiş ekonomiye sahip gelişmekte olan ülkeler için bu oran \%10-20 olarak hesaplanmaktadır (UNWTO 2007; UNCTAD 2010).

Birçok araştırmacı sızıntıları üç başlık altında sınıflandırmaktadır: içsel, dışsal ve görünmez sızıntılar (Diaz 2001; Gollub vd. 2003). İçsel sızıntılar, ithal edilmiş mal ve hizmetlere yönelik yapılan harcamaları kapsamaktadır. Bu durum, destinasyon ülkesindeki ulusal firmaların turizm endüstrisi için yeterli kalite veya miktarda mal ve hizmet üretme yeteneği olmaması sonucunda ithalata başvurulması ile ortaya çıkar. Dışsal sızıntılar ise iki farklı yolla ortaya çıkmaktadır. Bunlardan ilki, turist harcamasının bir kez de olsa destinasyon ülkesine dahil olduğu, ikincisi ise turist harcamasının hiçbir şekilde destinasyon ülkesine ulaşmadığı durumlardır. İlki yabancı yatırımcların kar transferleri, yabancı işgücü ücret ödemelerinin transferi ve deniz aşırı pazarlama maliyetleridir (Hemmati ve Koehler 2000;
Page ve Connell 2006; Lejarraga ve Walkenhorst 2007; Sandbrook 2010). İkinci olarak destinasyon ülkesine hiç ulaşmayan harcamalar ise uluslararası havayolları, tur operatörleri, seyahat acenteler, ve zincir otellerden kaynaklanmaktadır (Diaz 2001; Gollub vd. 2003; UNCTAD 2010). Görünmez sızıntılar güvenilir biçimde ve tam olarak ölçülemeyen ancak birikimli etkilere sahip olan kayıplar veya fırsat maliyetleri olarak değerlendirilmektedir. Bu sızıntıların temelinde uluslararası işlemlerde vergi muafiyeti ve deniz aşırı yatırımlar vb. gibi finansal unsurlar (Diaz 2001; Gollub vd. 2003) ve doğal kaynakların zarar görmesi vb. gibi fiziksel unsurlar bulunmaktadır².

\section{MARMARIS OTELCILIK SEKTÖRÜNÜN GENEL EKONOMIK ETKISININ TAHMIN EDILMESI}

Bu bölümde 2013 sonu ve 2014 başlarında Marmaris otelcilik sektöründe yapılan alan araştırmasından elde edilen verilerle Marmaris geneli için otelcilik endüstrisinin ekonomik etkilerini tahmin etmek üzere üç farklı durum ele alınmıştır $^{3}$. İlkinde veri elde edilen örneklemin araştırma kapsamının (ana kütle) yatak kapasitesinin $\% 79$ 'unu, ikincisinde örneklemin yatak kapasitesinin 3, 4 ve 5 yıldızlı otellerin yatak kapasitesinin $\% 63,7^{\prime}$ sini ve üçüncüsünde örneklemin tüm Marmaris yatak kapasitesinin \%52'sini oluşturması üzerine Marmaris'in tamamina (\%100'üne) tekabül eden değerleri hesaplanmıştır". Böylelik-

\footnotetext{
${ }^{2}$ Alanyazında, turizmde kar transferleri, tur operatörlerinin payı ve işgücü ithalatı gibi faktörlerle beslenen dışsal sızıntıları konu edinen araștırmalardan ziyade, turizmin diğer sektörler ile bağlantılarının boyutu ile ilişkili olan içsel sızıntıları konu edinen araştırmalar çoğunluktadır. Bu çalışmalardan birçoğunda, turizm ile gıda ve tarım sektörleri arasındaki bağlantılar ve sizıntılar (Varley 1978; Belisle 1983; Telfer ve Wall 1996; Momsen 1998; Torres 2002) araştırılmışken, az sayıda çalışmada turizmin diğer tüm sektörler ile bağlantıları ve sızıntıları (Kirsten ve Rogerson 2002; Mshenga ve Owour 2009) üzerine yoğunlaşılmıştır. Türkiye'de sızıntıların kaynağı ve nedenleri ile ilgili kapsamlı bir çalışma için bakınız Terzioğlu (2014).

${ }^{3}$ Araştırma kapsamında 52 tesis (20 tanesi 5 yıldızlı, 27 tanesi 4 yıldızlı, 5 tanesi 4 ve 5 yıldızlı tatil köyü) yer almaktadır. $\mathrm{Bu}$ otellerin tümüne ziyaret gerçekleştirilmesine rağmen 33 otel anket ve görüşme sorularının tümüne yanıt vermiştir. Hiçbir tatil köyü ankete katılmamıştır. Anket kapsamı içindeki cevap oranı \%63,5 (33/52) olarak gerçekleşmiştir.

${ }^{4}$ Alan araştırmasında ulaşılan 33 otelin toplam yatak kapasitesi 18.922'dir. Araştırma kapsamındaki 52 otelin toplam yatak ka-
} 
le üç farklı tahmin yapılmıştır. Tablolarda ikinci sütun araştırma bulgularını verirken, üçüncü sütun örneklem otellerine, dördüncü sütun 3, 4 ve 5 yıldızlı otellere ve beşinci sütun Marmaris'in tamamına yönelik tahmin sonuçlarını vermektedir.

Tahminlerden sonuncusunun abartılı sonuçlar verdiği izleyen tablolardan görülebilir. Bunun nedeni, bir ve iki yıldızlı oteller ile apart otellerin dört ve beş yıldızlı oteller ile benzer bir üretim yapısının olmamasından kaynaklanmaktadır. Üç yıldızlı otellerin genel olarak her şey dahil hizmet verdiği düşünülürse, 3,4 ve 5 yıldızlı oteller dikkate alınarak yapılan tahminlerin daha gerçekçi sonuçlar verdiği düşünülmektedir. Bu yüzden bu bölümde sadece bu tahminler tartışılmakta, ancak karşılaştırma yapılabilme açısından diğer tahminler de tabloda verilmektedir.

İlk olarak otellerin istihdam yaratma ve bunun sonucunda çarpan etkisi ile ortaya çıkan uyarılmış etkiler tahmin edilmiş, daha sonra ise otellerin satın alma davranışlarının ekonomik etkileri tartışlmıştır. Ardından, otellerin gelir ve giderleri tahmin edilerek yarattıkları katma değer üzerine öngörülere yer verilmiştir. Son olarak sektörde ortaya çıkan dışsal sızıntının boyutu tahmin edilmiştir.

\section{Otel İstihdam ve Ücret Gelirleri Etkisi}

Araştırma kapsamında otellerin ortalama çalışan sayıları ile nitelikleri ve aldıkları aylık ortalama ücret verileri elde edilmiştir. Bu verilere göre toplam çalışan sayısı örneklem için 3.808 iken bu değer 3, 4, ve 5 yıldızlı oteller için 5.978 olarak tahmin edilmektedir. Araştırma bulgularına göre

\footnotetext{
${ }^{4}$ pasitesi ise 23.948 'dir. Marmaris'in y1ldızlı oteller, pansiyonlar ve butik otellerle birlikte toplam yatak kapasitesi ise $36.285^{\prime}$ tir (MIKTM 2013). Bu otellerden 3 yıldızlı olanlar daha düşük kaliteli hizmet sunsalar da her şey dahil hizmet vermeleri nedeniyle araştırma örneklemine benzer bir istihdam yaratma ve satın alma davranışına sahip oldukları varsayılabilir. Diğer oteller (1 ve 2 yıldızl, apart oteller ve butik oteller) ise ya oda kahvaltı, ya yarım pansiyon ya da sadece oda şeklinde hizmet vermektedirler. Dolayısıyla 4 ve 5 yıldızlı otellere 3 yıldızlı otellerin ilave edilmesiyle geri ekonomik etkileri bakımından Marmaris otelcilik sektörü hakkında genellemeler yapılabilir. 3 yıldızlı oteller ile araștırma ana kütlenin toplam yatak kapasitesi 23.948'den 29.698'e yükselmektedir (MIKTM 2013). Böylece ulaşılabilen otellerin 3, 4 ve 5 yıldızlı otellerin yatak kapasitesi içindeki payı $\% 63,7$ olarak hesaplanmaktadir.
}

yöneticiler aylık ortalama 3.215.5, nitelikli personel 2.031,8 ve niteliksiz personel 983,3 TL almaktadır. Bu verilere göre bu kişilere ödenen toplam ücretin aylık olarak örneklem için 4,99 milyon TL olduğu hesaplanırken, 3, 4 ve 5 yıldızlı oteller için 7,83 milyon TL olarak tahmin edilmektedir.

$\mathrm{Bu}$ yolla elde edilen toplam ücret ödemeleri bir ay boyunca otellerde istihdam edilen personele yönelik yapılan toplam ücret ödemelerini vermektedir. Bu ücret ödemeleri işgücünün aylık toplam gelirini oluşturmaktadır. Bu gelirin tüketime ayrılan kısmı bu kesimin toplam tüketim harcamalarını verecek ve tüketim harcamaları da harcama çarpanı yoluyla ekonomiye dolaylı etkide bulunacaktır. İşçiler elde ettikleri geliri harcadığında ise harcama yoluyla ekonomiye katkı yapacaklardır. Çarpan etkisi denilen bu harcamaların ekonomiye etkisi aşağıdaki formülle hesaplanmaktadır. Çarpan katsayısının büyüklüğü (kapalı ekonomi varsayımı altında) marjinal tüketim eğilimi (c) ve marjinal vergi oranı ( $t$ ) tarafından belirlenmektedir.

$$
k=\frac{c}{1-\mathrm{c}(1-\mathrm{t})}
$$

Türkiye için yapılan çalışmada marjinal vergi oranının \%17 ve marjinal tüketim eğiliminin $\% 70$ olduğu hesaplanmıştır (Özker 2001). Otellerde istihdam edilen işgücü üç ana grupta (yönetici, nitelikli ve niteliksiz) değerlendirilmektedir. $\mathrm{Bu}$ grupların eğitim düzeyi ve niteliklerine göre ücretleri farklılık gösterdiği gibi gelirlerini tüketme ve tasarruf etme eğilimleri de farklılık göstermektedir. Gelir düzeyi yükseldikçe tüketim eğilimlerinin düştüğü ve tasarruf eğilimlerinin yükseldiği kabul edilebilir. Bu doğrultuda basitleştirici bir genelleme ile niteliksiz, nitelikli ve yönetici personelin marjinal tüketim eğiliminin sırasıyla \%80, \%70 ve \%60 olduğu varsayılmıştır. Dolayısıyla çarpan katsayısı yöneticiler $(1,195)$, nitelikli $(1,671)$ ve niteliksiz personel $(2,381)$ için farklı bulunmaktadır.

Tablo 2'de çalışanların niteliklerine göre, çarpan katsayıları yardımıyla hesaplanan toplam aylık ve yıllık etkilere yer verilmektedir. Aylık yaratılan toplam etkinin örneklem bazında 9,99 milyon TL olduğu görülmektedir. Bu etkinin 3, 
Turizmin Yerel Ekonomik Etkilerinin Belirlenmesi: Marmaris Otelcilik Endüstrisi Örneği

Tablo 1. Niteliklerine Göre Çalışan Sayıları ve Aylık Toplam Ücret Ödemeleri

\begin{tabular}{|c|c|c|c|c|}
\hline \multicolumn{5}{|c|}{ Çalışan Sayıları } \\
\hline & Örneklem otelleri & 4 ve 5 yıldızlı oteller & 3, 4 ve 5 yıldızlı oteller & $\begin{array}{r}\text { Tüm Marmaris } \\
\text { otelleri }\end{array}$ \\
\hline Yönetici & 228 & 289 & 358 & 438 \\
\hline Nitelikli personel & 703 & 890 & 1.104 & 1.352 \\
\hline Niteliksiz personel & 2.877 & 3.642 & 4.516 & 5.533 \\
\hline Toplam & 3.808 & 4.820 & 5.978 & 7.323 \\
\hline \multicolumn{5}{|c|}{ Ücret Ödemeleri (Aylık-TL) } \\
\hline & Örneklem otelleri & 4 ve 5 yıldızlı oteller & 3, 4 ve 5 yıldızlı oteller & $\begin{array}{r}\text { Tüm Marmaris } \\
\text { otelleri }\end{array}$ \\
\hline Yönetici & $733.134,00$ & $928.017,72$ & $1.150 .916,80$ & $1.409 .873,08$ \\
\hline Nitelikli personel & $1.428 .355,40$ & $1.808 .044,81$ & $2.242 .316,17$ & $2.746 .837,31$ \\
\hline Niteliksiz personel & $2.828 .954,10$ & $3.580 .954,56$ & $4.441 .058,24$ & $5.440 .296,35$ \\
\hline Toplam & $4.990 .443,50$ & $6.317 .017,09$ & 7.834.291,21 & $9.597 .006,73$ \\
\hline
\end{tabular}

4 ve 5 yıldızlı otellerin tümü için 15,6 milyon TL olduğu tahmin edilmektedir. Bu etki yıllık olarak da hesaplanabilir. Araştırma bulgularına göre, yöneticilerin $\% 89,5^{\prime} i$, nitelikli personelin $\% 26,1^{\prime} \mathrm{i}$ tam zamanlı iken niteliksiz personelin \%91,5'i sezonluk olarak istihdam edilmektedir. Ayrıca araştırma bulgularından otellerin çalışma dönemlerinin ortalama altı ayı (Mayıs-Kasım) kapsadığı görülmektedir. Buradan hareketle ücret harcamaları ve bunların sezonluk veya tam zamanlı ağırlıkları dikkate alınarak yarattı $\breve{g}_{1}$ toplam etki hesaplanabilir ${ }^{5}$. Buna göre ücret ödemelerinin yıllık çarpan etkisi örneklem bazında yaklaşık 71,8 milyon TL olarak hesaplanmaktadır. Aynı etkinin 3, 4 ve 5 yıldızlı otellerin tümü için 112,8 milyon TL olduğu tahmin edilmektedir. Yani otelcilik sektöründe çalışanlara yapılan ücret ödemeleri çarpan etkisiyle Marmaris ekonomisinde yaklaşık 113 milyon TL harcamaya neden olmaktadir.

\section{Otel Harcama ve İthalat Etkisi}

Alan araştırmasında otellerin hizmet üretmek amacıyla satın aldı ̆̆ı yiyecek ve içecek harca-

\footnotetext{
5 Örneğin; nitelikli personel için, çalışanların \%26,1'ine 12 ay boyunca (tam zamanl1) ücret ödendiği ve \%73,9' una 6 ay boyunca (sezonluk) ücret ödendiği bilindiğinden toplam ücret ödemeleri buna göre hesaplanmıştır
}

maları ile bu harcamalardan ortaya çıkan ithalat sızıntısı olup olmadığ 1 sorulmuş ve bazı ürün gruplarında ithal girdi kullanımının olduğu ortaya çıkmıştır. Tablo 3'te otellerin yiyecek ve içecek ürün gruplarına yönelik yaptıkları sezonluk harcama tutarları ve bu ürün gruplarına yönelik ithalat harcamalarına yer verilmektedir. Toplam harcamalar örneklem otelleri için 59,3 milyon TL olarak hesaplanırken, 3, 4 ve 5 yıldızlı otellerin tümü için 93,0 milyon TL olarak tahmin edilmektedir. Toplam harcamalar içindeki ithalat harcamaları payının \%7,4 olduğu hesaplanmıştır.

$\mathrm{Bu}$ harcamalar Marmaris ekonomisi için otelcilik sektörünün yarattığı ilk toplam talep ve toplam harcama olarak kabul edilebilir. Yerel ekonomiye yönelik yapılan harcamalar çarpan mekanizmasıyla ekonomi genelinde önemli miktarda bir etki yaratmaktadır. Uygulamada marjinal vergi oranı (t) \%17 ve marjinal tüketim eğilimi (c) \%70 olarak kabul edildiğinden, Keynesyen harcama çarpanı ${ }^{6}$ 2,38 olarak hesaplanmaktadır. Çarpan katsayısı ile birlikte toplam etki örneklem bazında 130,7 milyon TL ve 3,4 ve 5 yıldızlı otellerin tümü için $(54,9$ X 2,38) 205,1 milyon

\footnotetext{
6

$k=\frac{1}{1-\mathrm{c}(1-\mathrm{t})}=\frac{1}{1-0,7(1-0,17)}=2,38$
} 
Mustafa Terzioğlu - Ummuhan Gökovalı

Tablo 2. Çalışanların Niteliklerine Göre Ödenen Ücretlerin Toplam Etkileri (Aylık ve Yıllık) (TL)

\begin{tabular}{|c|c|c|c|c|}
\hline \multicolumn{5}{|c|}{ Aylık Etkiler } \\
\hline & Örneklem otelleri & 4 ve 5 yıldızlı oteller & 3, 4 ve 5 yıldızlı oteller & $\begin{array}{r}\text { Tüm Marmaris } \\
\text { otelleri }\end{array}$ \\
\hline Yönetici & $876.095,13$ & $1.108 .981,18$ & $1.375 .345,57$ & $1.684 .798,33$ \\
\hline Nitelikli personel & $2.386 .781,87$ & $3.021 .242,88$ & 3.746.910,32 & $4.589 .965,14$ \\
\hline Niteliksiz personel & $6.735 .739,71$ & $8.526 .252,80$ & $10.574 .159,67$ & $12.953 .345,60$ \\
\hline \multirow[t]{3}{*}{ Toplam } & $9.998 .616,72$ & $12.656 .476,86$ & $15.696 .415,57$ & 19.228.109,07 \\
\hline & \multicolumn{4}{|c|}{ Yıllık Etkiler } \\
\hline & Örneklem otelleri & 4 ve 5 yıldızlı oteller & 3,4 ve 5 yıldızlı oteller & $\begin{array}{r}\text { Tüm Marmaris } \\
\text { otelleri }\end{array}$ \\
\hline Yönetici & $9.961 .201,63$ & $12.609 .115,98$ & $15.637 .679,16$ & 19.156.156,98 \\
\hline Nitelikli personel & $18.058 .391,65$ & $22.858 .723,61$ & $28.349 .123,48$ & $34.727 .676,26$ \\
\hline Niteliksiz personel & $43.849 .665,53$ & $55.505 .905,73$ & $68.837 .779,48$ & $84.326 .279,86$ \\
\hline Toplam & $71.869 .258,81$ & $90.973 .745,33$ & $112.824 .582,12$ & $138.210 .113,09$ \\
\hline
\end{tabular}

TL olarak hesaplanmaktadır. Yani otellerin yerel (ulusal) ekonomiden satın aldığı girdilere yapılan harcamalar ekonomide tekrar harcandığından dolayı toplam etki 205,1 milyon TL'dir.

\section{Otel Gelirleri Etkisi}

Araştırma kapsamında elde edilen verilerden hareketle otel gelirlerinin ortalama olarak $\% 93,42$ 'si oda gelirlerinden oluşmaktadır. Otel yöneticilerinden edinilen verilere göre ortalama sezonluk oda fiyatı 277,6 TL'dir. Buna ek olarak, otellerin toplam çalışma gün sayısı, çalışma dönemlerindeki ortalama doluluk oranı ve oda sayıları görüşmeler kapsamında yöneticilerden alınan veriler arasındadır. Bu veriler ile otellerin sezon boyunca elde ettikleri oda gelirleri hesaplanabilir. Bu hesaplama için aşağıdaki formül kullanılmıştır.

$$
\sum_{1}^{33} \text { Sezonluk Aktif Oda X Fiyat }=Y
$$

Sezonluk aktif oda sayısı, toplam çalışma gün sayısı (6 ay: 180 gün), çalışma dönemlerindeki ortalama doluluk oranı $(\% 88,5)$ ve oda sayıları verileri yardımıyla hesaplanmaktadır. Fiyat ise her bir otelin beyan ettiği oda fiyatıdır. Yukarıdaki hesaplama ile toplam gelir (Y) 504,9 milyon TL ve otel başına ortalama gelir 15,3 milyon TL olmaktadır. Bu değerler sezonluk oda gelirini verirken, otelin toplam gelirlerinin \%93,42'sini oluşturmaktadır. Bu bakış açısı ile her bir otelin toplam geliri 16,377 milyon TL olarak tahmin edilmektedir. Diğer taraftan otellerin dayanıksız girdi maliyet tutarları ve toplam maliyetler içinde ürün gruplarının payı da bilindiğinden, otellerin toplam giderleri tahmin edilebilir. Araştırmada otellerin ortalama yiyecek ve içecek giderleri 1,688 milyon TL ve yiyecek ve içecek giderlerinin toplam giderler içindeki payının \%31,46 olduğu tespit edilmiştir. Böylelikle otellerin toplam maliyeti (1,688 / 31,46 X 100) kabaca 5,367 milyon TL olarak hesaplanabilir.

Tablo 3. Otellerin Dayanıksız Ürün Gruplarına Yönelik Yaptığ1 Harcamalar (TL)

\begin{tabular}{lrrr}
\hline & Örneklem otelleri & 4 ve 5 yıldızlı oteller & $\begin{array}{r}\text { 3, } 4 \text { ve 5 yıldılı oteller } \\
\text { Tüm Marmaris } \\
\text { otelleri }\end{array}$ \\
\hline Ithalat Harcamaları & $4.387 .300,00$ & $5.553 .544,30$ & $6.887 .441,13$ \\
\hline Yerel Harcamalar & $54.912 .700,00$ & $69.509 .746,84$ & $86.205 .180,53$ \\
\hline
\end{tabular}


Turizmin Yerel Ekonomik Etkilerinin Belirlenmesi: Marmaris Otelcilik Endüstrisi Örneği

Tablo 4. Otel Başına, Örneklem Otelleri, 4 ve 5 Yıldızlı Oteller ve Tüm Marmaris Otelleri için Gelir, Gider, Kar ve Vergi Tutarları (Bin TL)

\begin{tabular}{lrrrrr}
\hline & Otel Başına & Örneklem otelleri & 4 ve 5 yıldılı oteller & 3, 4 ve 5 yıldızlı oteller & $\begin{array}{r}\text { Tüm Marmaris } \\
\text { otelleri }\end{array}$ \\
\hline Gelirler & 16.377 & 540.462 & 684.129 & 848.450 & 1.039 .350 \\
\hline Giderler & 5.367 & 177.116 & 224.197 & 278.047 & 340.607 \\
\hline Muhasebe Kârı & 11.010 & 363.346 & 459.932 & 570.402 & 698.742 \\
\hline Vergi Tutarı & 2.202 & 72.669 & 91.986 & 114.080 & 139.748 \\
\hline Net Kâr & 8.808 & 290.677 & 367.945 & 456.322 & 558.994 \\
\hline
\end{tabular}

Muhasebe karı, toplam gelirden toplam maliyetlerin çıkarılması ile bulunur. Bu değer (16,377 - 5,367) kabaca 11,0 milyon TL'dir. Bu değer üzerinden \%20 kurumlar vergisi ödendiği kabul edilirse ödenen vergi tutarı 2,2 milyon TL olmaktadır. Gelir, gider, kar ve vergi tutarları örneklem, 4 ve 5 yıldızlı, 3, 4 ve 5 yıldızlı oteller ile tüm Marmaris otelleri için hesaplanmış ve Tablo 4 'de yer verilmiştir. Otel başına hesaplanan vergi tutarı 2,2 milyon TL iken bu değer 3, 4 ve 5 yıldızlı oteller için 114,08 milyon TL bulunmuştur. $\mathrm{Bu}$ değer Marmaris otelcilik sektörünün devlete sağladığı vergi gelirini oluşturmaktadır. Marmaris otelcilik sektörünün yarattığ 1 vergi gelirinin kamu harcaması olarak ekonomiye ilave olduğu varsayılabilir. Dolayısıyla kamu harcamalarının etkisi çarpan mekanizması yoluyla oldukça yüksek olacaktır.

Otel başına gerçekleşen kar ise 8,8 milyon TL olarak bulunmuştur. Bu değer 3, 4 ve 5 yıldızlı oteller için toplam 456,3 milyon TL olarak tahmin edilmektedir. Bu tutarın bir kısmı tasarrufa ve kredi faiz ödemelerine ayrılırken, kalanı yenileme yatırımı harcamaları ve tüketim harcamaları olarak ekonomiye dahil olmaktadır. Dolayısıyla net kar üzerinden yine bir harcama yaratılmakta ve bu harcama çarpan etkisiyle toplam gelire önemli ölçüde katkıda bulunmaktadır.

\section{Otel Hizmet Türü ve Yabancı Sermaye Etkisi}

Otellerin hizmet türü incelendiğinde sadece üç otel dışında diğer tüm otellerin her şey dahil, ultra her şey dahil ve tam pansiyon türünde hizmet verdikleri görülmektedir. Turistlerin tüm yiyecek ve içecek ihtiyaçlarını otelin paket dahilindeki hizmetlerinden karşıladıkları ve yerel piyasa- dan önemli miktarda yiyecek ve içecek ürünleri satın almadıkları söylenebilir.

Ulaşılabilen otellerin sermaye yapısı incelendiğinde tamamının yerli sermaye yapısına sahip olduğu görülürken, araştırma kapsamında sermaye yapısında yabancı sermaye payı olan otel sayısı Marmaris genelinde sadece birkaç tanedir. Dolayısıyla Marmaris genelinde yabancı sermaye payı olan otel sayısı, yok denecek kadar azdır.

Yabancı sermaye payı tur operatörü sahipliğinde ortaya çıkmaktadır. Müşterilerin rezervasyon yöntemleri incelendiğinde bireysel ve yerinde rezervasyon yönteminden çok yerli/yabancı operatör/acente aracılığıyla rezervasyon yönteminin tercih edildiği görülmektedir. Yabancı tur operatörü/acentesi aracılığıyla rezervasyon yöntemi \%76,43'lük pay ile ilk sırada yer almaktadır.

Yöneticiler ile yapılan görüşmelerden elde edilen bilgilere göre müşterilerin paket tatil ödemeleri içinde otelin aldığ 1 pay ortalama olarak $\% 45,46$ olarak hesaplanmıştır. Otelin aldığı paydan geriye kalan yaklaşık \%55'lik pay, uluslararası ulaşım (hava yolu) ve yerel ulaşım (hava alanı-otel transferi), yabancı tur operatörü kar payı ve incoming acenta (karşılayan) kar payı olmak üzere temelde dört faktörden oluşmaktadır. Turistlerin paket tatil harcamalarından en az pay elde eden paydaşın incoming acenta ve yerel ulaşım olduğu ve paylarının yaklaşık \%10 olduğu ifade edilmektedir. TÜİK, yaptığı ‘Tur Operatörü Anketi' sonuçlarına göre ulusal turizm gelirlerini hesaplarken, 2012 yılından itibaren Türkiye'ye kalan paket tur oranını \%54 olarak tespit etmiştir (TÜİK 2012). Dolayısıyla araştırma kapsamında ulusal sınırlar içinde kaldığı tespit edilen değer (otellerin ve diğer yerel paydaşların toplamı 
olan \%55,46) TÜíK'in kabul ettiği değer (\%54) ile uyumludur. Bu durumda turistlerin paket tatil ödemelerinin ortalama \%55'i yerel ekonomiye dahil olurken, kalan \%45'i ise dışsal sızıntı olarak çıkış ülkesinde kalmaktadır.

Araştırma bulgularına göre turistlerin paket tatil harcamalarından otele kalan pay (\%45) ile yurt dışında kalan pay (\%45) birbirine eşittir. Paket tatil harcamalarindan otele kalan harcama tutar1 (oda geliri) 15,3 milyon TL olarak hesapland1ğından yurt dışında kalan harcama tutarı da (dışsal sızıntı) ortalama olarak otel başına bu değere eşittir. Bu veriden hareketle, dışsal sızıntı tutarı örneklem için 504,9 milyon TL olarak hesaplanmakta, 3, 4 ve 5 yıldızlı otellerin tümü için $(504,9$ / 63,7 X 100) 792,6 milyon TL olarak tahmin edilmektedir. Dolayısıyla turist harcamalarının çok önemli bir kısmının ülke ekonomisine hiçbir katkısı olmamakta ve yabancı tur operatörlerinin elinde kalmaktadır.

\section{GENEL DEĞERLENDIRME VE POLiTiKA ÖNERILERI}

Bu çalışmada Marmaris'te faaliyet göstermekte olan 4 ve 5 yıldızlı otel ve tatil köylerinin geri ekonomik bağlantı ve sızıntıları aracılığı ile yerel/ ulusal ekonomiye katkıları çarpan analizi yönte$\mathrm{mi}$ ile incelenmiştir. Bulgular otelcilik endüstrisinin istihdam yaratma kapasitesinin yüksekliğini (yaklaşık 6000 kişi) ve yapılan ücret ödemelerinin çarpan etkisi ile Marmaris ekonomisine önemli katkılar (yaklaşık aylık 16 milyon TL) sağladığını göstermektedir. Ayrıca otelcilik endüstrisinin dayanıksız girdi harcamaları yoluyla yerel ve ulusal ekonomiye önemli katkılar yaptığ 1 ve elde ettiği işletme gelirlerinden önemli bir miktarda kâr elde edilerek devlete önemli miktarlarda vergi ödemesi yapıldığı tespit edilmiştir.

Çalışmanın önemli bulgularından biri otelcilik endüstrisinde temel olarak iki sızıntı kaynağının ortaya çıkmasıdır. Bu sızıntılar Marmaris otelcilik endüstrisinde yabancı tur/acenta baskınlığı ve ithal girdi kullanımı yoluyla ortaya çıkmaktadır. Yabancı tur operatörlerinin baskınlığı yoluyla ortaya çıkan sızıntının boyutları (toplam turist harcamalarının \%45'i) oldukça büyüktür. Bu sızıntı otelcilik endüstrisinin Marmaris'te yaptığ 1 katkıya eşdeğerdir. Tur operatörlerinin baskınlığını artırıcı faktörlerin başında ise turistlerin bireysel olarak rezervasyon yapma oranının düşüklüğü gelmektedir. Bireysel rezervasyon yapma sürecinin ise iki ana unsuru söz konusudur. Bunlardan ilki turistlerin oteller ile doğrudan bağlantı kurabilmesi ve ikincisi çıkış ülkesinden varış ülkesine ulaşımın sağlanmasıdır. Mevcut durumda iki unsurda da önemli eksiklikler bulunmaktadır. Tur operatörlerinin baskınlığını azaltmak üzere turistlerin bireysel rezervasyonlarını artırmaya yönelik oluşturulacak politikaların bu konularda önceliklendirilmesi gerekmektedir.

İlk olarak, turistlerin oteller ile doğrudan bağlantıya geçebileceği sanal veya görsel ortamların daha etkin bir şekilde kullanıma sunulması gerekmektedir. Bu aşamada rezervasyon dönemlerinde tatmin edici tanitımların ve turistlerin endişelerini giderici aydınlatıcı bilgilendirme faaliyetlerinin yapılması ve çıkış ülkelerinde tanıtım ve bilgilendirme amaçlı acente, ofis veya temsilcilik açılması/verilmesi gerekmektedir.

Turistlerin çıkış ülkesinden Türkiye'ye yerel hava yolu şirketlerinin uçuşlarının yabancı tur operatörlerinin uçuşlarına göre hem istenen sıklıkta olmaması hem de fiyat bakımından yüksek olması diğer önemli sorunlardandır. Bu aşamada yabancı tur operatörlerinin sermaye yapılarının çok güçlü olması nedeniyle sahip oldukları bürokratik nüfuz gücü bu operatörlere önemli avantajlar sağlamaktadır. Bu operatörler kendi ülkelerinden varış ülkelerine (Türkiye'ye) uçuş yapmak isteyen yabancı havayolu şirketlerine bürokratik nüfuz güçlerinin kullanarak bazı engeller oluşturmaktadırlar. Yapılan derinlemesine görüşmelerde yöneticiler, operatörlerin yabancı havayolu şirketlerine çok yüksek havaalanı vergileri uygulanmasını sağlayarak uçuşun maliyetini artırıp, karlılığını düşürdüklerini belirtmişlerdir. Bu aşamada ülkelerarası anlaşmalar yoluyla bu tür engellemelerin önüne geçmek mümkün olabilir. Yerel kamu kurumlarının çıkış ülkesi kamu kurumları ile görüşmeler yapıp yerel havayolu şirketlerinin daha kolay uçuş yapabilmelerine zemin hazırlamaları gerekmektedir.

Rezervasyon sürecinde yabancı tur operatörlerinin aradan çıkarılamadığı durumlarda, operatörlerin paket tatil harcamalarından aldıkları 
payı azaltıcı politikalar uygulanabilir. Fiyat belirleme aşamasında bölgedeki otel yönetimlerinin turizm/otel birlikleri şemsiyesi altında ortak fiyat politikası izlemeleri otel yönetimlerine belli bir pazarlık gücü kazandırabilir. Hizmet ve otel sınıfı türlerine göre alt limit fiyatlarının belirlenmesi, ortak fiyat politikasına örnek olarak verilebilir. Oteller arası rekabetin azaltılarak, birlik halinde yabancı tur operatörü ile rekabet edilmesi akla daha yatkın gelmektedir. Bu aşamada, otel yöneticilerinin sezonluk ve kişisel hırslarından arınmış olmaları ve geniş bir vizyona sahip olmaları bu sürece olumlu katkı sağlayacaktır. Fiyat pazarlığı sürecinde, yabancı tur operatörlerinin pazarlık gücünü artırıcı en önemli etken yerel tesis ve hizmet kalitesinin yeterli olmamasıdır ${ }^{7}$. Bu nedenle tesise yönelik iyileştirme yatırımlarının yapılması otellerin pazarlık gücünü artıracaktır.

Ekonomik sızıntıya neden olan bir diğer unsur ise ithal girdi kullanımıdır. İthal girdi kullanımının en fazla olduğu ürünlerin yer aldığı ürün grupları balıklar ve alkollü içeceklerdir. Bu ürün gruplarında her bir sektörün öncü firmaları ile görüşülerek otelcilik sektörünün beklentilerine (fiyat, kalite ve kullanılabilirlik bakımından) uygun ürünler üretilmesi gerekmektedir. Birçok ürün grubunda yerel girdi kullanımı söz konusu olsa da alımların doğrudan üreticilerden değil genellikle aracılar yoluyla (toptancı vb.) yapıldığ 1 tespit edilmiştir. Bunun en temel nedeni olarak özellikle tarımsal üretimde küçük ölçekli aile işletmelerinin piyasada çoğunlukta olmaları gösterilmektedir. Yöneticilerin beyanına göre, düşük sezonda ihtiyaç duyulan tarımsal ürünleri doğrudan üreticiden karşılama imkânı olsa da yüksek sezondaki talep miktarını veya anlık talep artışlarını üreticilerin doğrudan karşılama imkânının olmadığı görülmektedir. Dolayısıyla, özellikle tarımsal ürün üreticilerinin üretim ölçeklerinin genişletilmesi veya üretici birlikleri oluşturulması yoluyla otellerin girdi talebini kar-

\footnotetext{
${ }^{7}$ Yapılan derinlemesine görüşmelerde yöneticiler tur operatörlerinin tesis ve hizmet kalitesini belirlemek amaciyla uzmanlarını tesislere göndererek detaylı bir inceleme yaptırdıklarını ayrica tatil bitiminde konaklama yapan turistlere memnuniyet anketi yaptırarak buna göre her bir otelin oda fiyatını belirlediğini beyan etmişlerdir.
}

şılayacak ölçeğe ulaşmaları gerekmektedir. Bu sayede, oteller girdi teminini doğrudan üreticiden yapabilecek ve üreticinin elde ettiği getirinin payında yükselme sağlanabilecektir.

Yerel ekonomi ile turizm sektörünün bağlantılarını zayıflatan bir diğer unsur her şey dahil hizmet türüdür. Her şey dahil hizmet türünde, turistler neredeyse tüm ihtiyaçlarını paket tatil kapsamında gidermekte ve turistler otel dışına çıkıp yerel esnaftan alış veriş yapma ihtiyacı hissetmemektedirler. Bu da turistlerin yerel ekonomi ile bağlantılarını zayıflatmaktadır. Ayrıca her şey dahil hizmet türü, büyük kitlelere hizmet verdiğinden küçük planlama hataları ile büyük kaynak israfına (özellikle yiyecek) neden olabilmektedir. Bununla beraber hizmet verilen kitlenin ve tesislerin büyüklüğü ile doğru orantılı olarak birçok doğal kaynağın (körfez, koy, deniz, orman, içme suyu vb.) tahrip olmasına ve yok olmasına neden olmaktadır. Atık ve çöplerin geri dönüşümünün veya arıtmasının yeterince yapılamaması çevresel olumsuz etkiyi iyice artırmaktadır. Bu gibi nedenlerle her şey dahil hizmet türü teşvik edilmemeli, yerine turistlerin yerel ekonomi ile bağlantılarını artıran yarım pansiyon, oda-kahvaltı gibi hizmet türleri teşvik edilmelidir.

\section{KAYNAKÇA}

Aguayo, E. (2011). Impact of Tourism on Employment: An Econometric Model of 50 CEEB Regions, Regional and Sectoral Economic Studies, 11 (1): 37-46.

Akama, J. S. ve Kieti, D. M. (2007). Tourism and Socio-economic Development in Developing Countries: A Case Study of Mombasa Resort in Kenya, Journal of Sustainable Tourism, 15 (6): 735-748.

Archer, B. ve Fletcher, J. (1996). The Economic Impact of Tourism in the Seychelles, Annals of Tourism Research, 23 (1): 32-47.

Belisle, F. J. (1983). Tourism and Food Production in the Caribbean, Annals of Tourism Research, 10: 497-513.

Britton, S. (1982). The Political Economy of Tourism in the Third World, Annals of Tourism Research, 9: 331-358.

Bryden, J. (1973). Tourism and Development: A Case Study of the Commonwealth Caribbean. Cambridge: Cambridge Üniversitesi Yayınları.

Diaz, D., (2001). Symposium on Tourism Services: The Viability and Sustainability of International Tourism in Developing Countries. World Trade Organization: Geneva.

Dritsakis, N. (2012). Tourism Development and Economic Frowth in Seven Mediterranean Countries: A Panel Data Approach, Tourism Economics, 18 (4): 801-816. 
Eugenio-Martin, J. L., Morales, N. M. ve Scarpa, R. (2004). Tourism and Economic Growth in Latin American Countries: A Panel Data Approach. FEEM Working Paper No. 26.2004.

Gollub, J., Hosier, A. ve Woo, G. (2003). Using Cluster-Based Economic Strategy to Minimize Tourism Leakages. UNWTO.

Gökovalı, U. (2010). Contribution of Tourism to Economic Growth in Turkey, Anatolia: International Journal of Tourism and Hospitality Research, 21 (1): 139-153.

Hanafiah, M. H. M. ve Harun, M. F. M. (2010). Tourism Demand in Malaysia: A Cross-Sectional Pool Time-Series Analysis, International Journal of Trade, Economics and Finance, 1 (2): 200-203.

Hemmati, M. ve Koehler, N. (2000). Financial Leakages in Tourism, Sustainable Travel and Tourism, 25-29.

International Labour Organization (2008). Guide for Social Dialogue in the Tourism Industry. Sectoral Activities Programme, Working Paper No: 265, Geneva.

Ivanov, S. ve Webster, C. (2013). Tourism's Contribution to Economic Growth: A Global Analysis for the First Decade of the Millenium, Tourism Economics, 19 (3): 477-508.

Kirsten, M. ve Rogerson, C. M. (2002). Tourism, Business Linkages and Small Enterprise Development in South Africa, Development Southern Africa, 19 (1): 29-59.

Lejárraga, I. ve Walkenhorst, P. (2007). Diversification by Deepening Linkages with Tourism. Dünya Bankası, Washington.

Mathieson, A. ve Wall, G. (1982). Tourism: Economic Physical and Social Impacts. ABD: Longman.

Momsen, J. (1998). Caribbean Tourism and Agriculture: New Linkages in the Global Era. T. Klak (Ed), Globalization and Neoliberalism: The Caribbean Context, İngiltere: Rowman \& Littleman Yayınları.

Moore, W. ve Craigwell, R. (2008). Foreign Direct Investment and Tourism in SIDS: Evidence from Panel Causality Tests, Tourism Analysis, 13 (4): 427-432.

Mshenga, P. M. ve Owuor, G. (2009). Opportunities for Micro and Small Scale Busines in the Tourism Sector: The Case of The Kenya Coast, KCA Journal of Business Management, 2 (2): 52-68.

Muğla İl Kültür ve Turizm Müdürlüğü (MiKTM) (2013). İstatistikler, Tesisler, İşletme ve Yatırım Belgeli Tesisler Oda Yatak Kapasitesi, http://www.muglakulturturizm. gov.tr/TR,73736/isletme-ve-yatirim-belgeli-tesisler-odayatak-kapasites-.html, Erişim tarihi: 15.12.2013.

Othman, R., Salleh, N.H.M. ve Sarmidi, T. (2012). Analysis of Causal Relationship Between Tourism Development, Economic Growth and Foreign Direct Investment: an ARDL Approach, Journal of Applied Sciences, 12: 12451254

Özker, A. N. (2001). Kamu Bütçesi Bileşenlerinde Endojenlik Olgusu ve Milli Gelir Denge İlişkisi, İstanbul Üniversitesi İktisat Fakültesi Maliye Araştırma Merkezi Konferansları, 40. Seri, İstanbul.

Page, S. J. ve Connell, J. (2006). Tourism: A Modern Synthesis. İkinci Bask1, Londra: Thomson Learning.

Roussot, E. W. (2005). International Tourism and Economic Development: A South African Perspective (Basılmamıs Yüksek Lisans Tezi), University of South Africa Sosyal Bilimler Yüksek Lisansı, İktisat Anabilim Dalı.
Sandbrook, C. G. (2010). Putting Leakage in its Place: The Significance of Retained Tourism Revenue in the Local Context in Rural Uganda, Journal of International Development, 22 (1): 124-136.

Sebastian, L. M. ve Rajagopalan, P. (2009). Socio-Culltural Transformation through Tourism: A Comparison of Residents' Perspectives at two Destinations in Kerala, India, Journal of Tourism and Cultural Change, 7 (1): 5-21.

Shan, J. ve Wilson, K. (2001). Causality between Trade and Tourism: Empirical Evidence from China, Applied Economic Letters, 8 (4): 279-283.

Sinclair, M. T. ve Stabler, M. (1997). The Economics of Tourism. Routledge.

Telfer, D. ve Wall, G. (1996). Linkages between Tourism and Food Production, Annals of Tourism Research, 23 (3): 635-653.

Terzioğlu, M. (2014). Turizm Endüstrisinde Geri Bağlantılar ve Ekonomik Sızıntılar: Marmaris Otelcilik Endüstrisi Örneği (Basılmamış Doktora Tezi). Muğla Sıtkı Koçman Üniversitesi Sosyal Bilimler Enstitüsü, İktisat Anabilim Dalı.

Torres, R. (2002). Toward a Better Understanding of Tourism and Agriculture Linkages in the Yucatan: Tourist Food Consumption and Preferences, Tourism Geographies: An International Journal of Tourism Space, Place and Environment, 4 (3): 282-306.

TÜİK (2012). Turizm İstatistikleri-2012. Yayın No: 3931, Ankara.

Tyrrell, T. ve Johnston, R. (2001). A Framework for Assessing Direct Economic Impacts of Tourism Events: Distinguishing Origins, Destinations, and Causes of Expenditures, Journal of Travel Research, 40 (1): 94-100.

UNCTAD (2010). The Contribution of Tourism to Trade and Development. Trade and Development Board, Geneva.

UNEP (2011). Towards a Green Economy: Pathways to Sustainable Development and Poverty Eradication. Part II: Investing in Energy And Resource Efficiency (Tourism).

UNEP ve UNWTO (2012). Tourism in the Green Economy-Background Report. Birleşmiş Milletler Dünya Turizm Örgütü, Madrid.

UNWTO (2002). Tourism and Poverty Alleviation. Birleşmiş Milletler Dünya Turizm Örgütü, Madrid.

UNWTO (2007). International Tourism Evolution in the Least Developed Countries since the Adoption of the Canary Islands Declaration. Meeting on the Trade and Development Implications of Tourism Services for Developng Countries: UNCTAD XII pre-event, Geneva.

UNWTO (2013). Tourism Highlights 2013 Edition. Birleşmiş Milletler Dünya Turizm Örgütü Yayınları, http:// dtxtq4w60xqpw.cloudfront.net/sites/all/files/pdf/unwto highlights13_en_lr_0.pdf, Erişim tarihi: 15 Şubat 2014.

Varley, R. C. G. (1978). Tourism in Fiji: Some Economic and Social Problems. Bangor Occasional Papers in Economics, Wales Press Üniversitesi.

Vellas, F. ve Becherel, L. (1995). International Tourism. Hampshire: MacMillan.

Wall, G. ve Mathieson, A. (2006). Tourism: Change, Impacts and Opportunities. Pearson Prentice Hall.

WTTC (2008). Progress and Priorities 2008/09. Washington, DC.

WTTC (2013). Travel and Tourism Economic Impact 2013-Turkey. http://www.wttc.org/site_media/uploads/ downloads/turkey2013.pdf, 17 Şubat 2014. 

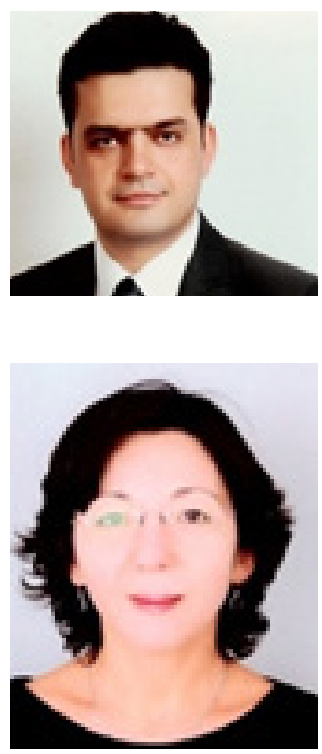

\section{Mustafa TERZioĞLU}

Dokuz Eylül Üniversitesi iiBF İktisat bölümünden mezun oldu (2004). Yüksek lisans derecesini Muğla Sıtkı Koçman Üniversitesi'nden İktisat Anabilim dalından (2008), doktora derecesini de Muğla Sıtkı Koçman Üniversitesi'nden İktisat Anabilim dalından aldı (2014). Muğla Sıtkı Koçman Üniversitesi'nde çalışmaya başladı (2005). Halen Muğla Sıtkı Koçman Üniversitesi iiBF İktisat bölümünde görev yapmaktadır. Temel çalışma alanları; turizm ekonomisi, sanayi ekonomisi ve mikro ekonomi'dir.

\section{Ummuhan GÖKOVALI}

Ankara Üniversitesi Siyasal Bilgiler Fakültesi İktisat bölümünden mezun oldu (1991). Yüksek lisans derecesini Oklahoma Devlet Üniversitesi İktisat Anabilim dalından (Oklahoma State University-Economics) (1996), doktora derecesini de Orta Doğu Teknik Üniversitesi'nden İktisat Anabilim dalından aldı (2003). Muğla Sıtkı Koçman Üniversitesi'nde çalışmaya başladı (2004). Doçentlik unvanını Uluslararası İktisat ve Gelișme İktisadı alanında aldı (2009). Profesörlüğe Muğla Sıtkı Koçman Üniversitesi'nde yükseltildi (2014). Halen Muğla Sıtkı Koçman Üniversitesi iiBF İktisat bölümünde görev yapmaktadır. Temel çalışma alanları; Fikri ve Sınai Mülkiyet Hakları, Turizm Ekonomisi ve Sağlık Ekonomisi'dir. 